\title{
LYMPHOPROLIFERATIVE DISEASE IN A COTTON-TOP MARMOSET AFTER INOCULATION WITH INFECTIOUS MONONUCLEOSIS-DERIVED EPSTEIN-BARR VIRUS
}

\author{
by
}

\author{
Jürgen Werner ', Hans Wolf ${ }^{2}$, Jesus APODACA ${ }^{1}$ and Harald zUR HAUSEN ${ }^{2}$ \\ ${ }^{1}$ Virusabteilung im Robert Koch-Institut des Bundesgesundheitsamtes, Nordufer 20, I Berlin 65; \\ and ${ }^{2}$ Institut für klinische Virologie der Universität Erlangen-Nürnberg, \\ Loschgestrasse 7,852 Erlangen, Germany
}

\begin{abstract}
Injection of concentrated $E B V$ derived from cells of the Kaplan line of infectious mononucleosis (IM) origin resulted in malignant lymphoproliferation in one out of three cotton-top marmosets 6 weeks after inoculation. Two additional animals receiving the same isolate after incubation with an antibody-containing human serum did not develop tumors. Inoculation of concentrated virus derived from the P3HR-I line of Burkitt origin did not lead to lymphoproliferation in five marmosets. Three of these received non-neutralized, and two received neutralized $P 3 H R-1$ virus. The tumor obtained with the Kaplan isolate revealed characteristics of a lymphosarcoma. It contained $E B V$-specific DNA. In addition, EBV-synthesizing lymphoblastoid lines were established from a tumorous lymph-node, as well as from the spleen of the diseased marmoset. Virus recovered from these lines transformed lymphocytes derived from spleens of healthy marmosets. The tumor-bearing animal developed low levels of anti-VCA antibodies during the course of tumor growth. These data demonstrate the oncogenic potential of EBV directly derived from cells of IM origin.
\end{abstract}

The etiological relationship of Epstein-Barr virus (EBV) to infectious mononucleosis (IM) has been firmly established (Henle et al., 1968; Niederman et al., 1968; Henle and Henle, 1970, 1971; Evans, 1974). EBV is also regularly demonstrated in another lymphoproliferative disease, Burkitt's lymphoma (BL) and in anaplastic nasopharyngeal carcinoma (NPC) (Henle et al., 1968; de Schryver et al., 1969; zur Hausen et al., 1970; Wolf et al., 1973; zur Hausen et al., 1974). Further proof of its oncogenicity was hampered by the lack of a suitable laboratory animal system. Infection of lymphocytes and subsequent transformation of cells derived from peripheral blood or spleen could be demonstrated for six sub-human primate species: gibbon, squirrel, cotton-top and white-lipped marmosets, cinnamon ringtail and owl monkeys (Falk et al.,
1972; Wolfe and Deinhardt, 1973; Deinhardt et al., 1974; Werner et al., 1972a).

Recently overt clinical illness has been reported in non-human primates after exposure to cell-free EBV or EBV-containing material (Shope et al., 1973; Epstein et al., 1973a; Falk et al., 1974). Shope and co-workers induced malignant lymphomas in four of eight cotton-top marmosets by inoculation of cell-free virus extracted from a marmoset lymphoblastoid line B95-8 originally transformed in vitro (Miller et al., 1972) by EBV isolated from an IM cell line. These results were confirmed by Falk and his colleagues, also using B95-8-derived virus in cotton-top marmosets. Epstein and his group inoculated owl monkeys with frozen and thawed EB3 cells of Burkitt origin and observed lymphoproliferative disease in one of three animals. These results indicate

Received: December 27, 1975, and in revised form March 27, 1975. 
that marmosets may provide an excellent laboratory model to study further the biological properties of different EBV preparations in vivo.

This report deals with responses of cotton-top marmosets to inoculation of two different preparations of EBV, of which one was active while the other had been exposed to EBV-specific antibody-containing human serum.

\section{MATERIAL AND METHODS}

\section{Marmosets}

Wild-caught, adult cotton-top marmosets (Saguinus oedipus) from Colombia, South America, were used in these experiments. The animals had been conditioned for laboratory use and were free of detectable antibodies against EBV.

\section{Virus}

Cells and supernatants $(1,400 \mathrm{ml}$ total vol. of each culture) of aged P3HR-1 cultures of BL origin (Hinuma et al., 1967) and of the IM-derived Kaplan line (Diehl et al., 1968) were subjected to differential centrifugation. After clarification at low speed, the virus was concentrated from the culture fluid at $36,000 \times \mathrm{g}$ for $2 \mathrm{~h}$ at $4^{\circ} \mathrm{C}$ in the No. 19 rotor of the Beckman preparative centrifuge. In addition, the cell pellet was resuspended in $15 \mathrm{ml}$ reticulocyte standard buffer (RSB) containing $0.01 \mathrm{M} \mathrm{NaCl}, 0.0015 \mathrm{M} \mathrm{MgCl}_{2}$, $0.01 \mathrm{~m}$ Tris $\mathrm{HCl} \mathrm{pH} \mathrm{7.4,} \mathrm{and} \mathrm{kept} \mathrm{at} 4^{\circ} \mathrm{C}$ for $3 \mathrm{~h}$, then dounced briefly and indirectly sonicated with the Branson macrotip sonifier for $1 \mathrm{~min}$ at position 4. After low-speed centrifugation the RSB-supernatant was pooled with the resuspended virus pellet recovered from the first highspeed run. The pooled material was then spun at $80,000 \times g$ for $1 \mathrm{~h}$ at $4^{\circ} \mathrm{C}$ in the Beckman SW 27 rotor. The resulting pellet was resuspended in $2.2 \mathrm{ml}$ of phosphate-buffered saline (PBS), dounced 10 times and passed through a $1.2 \mu$ membrane filter.

Corresponding preparations of P3HR-1 virus induced early antigens (EA) in about $20 \%$ of infected Raji cells $72 \mathrm{~h}$ post infection (PI) with the undiluted virus. The Kaplan concentrate transformed umbilical cord lymphocytes at a very low efficiency (dilutions $10^{0}$ to $10^{-1}$ ). The P3HR-1 line contained at the time of harvest about $5 \%$ viral capsid antigen (VCA)-positive cells, whereas the Kaplan line revealed approximately $0.1 \%$ VCA-positive cells as measured by immunofluorescence (IF).

\section{Neutralization}

Equal volumes of each virus preparation were incubated for $1 \mathrm{~h}$ at $37^{\circ} \mathrm{C}$ with the same amount of human EBV-reactive or non-reactive serum. The EBV-reactive serum revealed an anti-VCA titer of $1: 320$, and an anti-EA titer of $1: 2$. The non-reactive serum contained less than $1: 5$ of anti-VCA activity.

\section{Inoculation of marmosets and follow-up studies}

Ten randomly-selected male and female marmosets were inoculated with EBV preparations by the intramuscular route. Each of the P3HR-1 and Kaplan viral preparations was injected into three marmosets. Two additional animals received the appropriate virus inoculum after treatment of the concentrate with human anti-EBV serum. Equal amounts of active as well as non-active virus were injected into the left masseter muscle of the marmosets. The animals were bled from the femoral triangle at weekly intervals for white blood cell (WBC) counts and for antibody determinations. At each bleeding the marmosets were closely examined for evidence of tumor formation, as well as for clinical symptoms which might be referable to EBV infection. Blood samples obtained were examined for hematological abnormalities and antibody activity referable to EBV infection.

\section{Immunofluorescence}

For antibody determination, sera collected from the marmosets were tested by the indirect immunofluorescence (IF) techniques described by the Henles (Henle and Henle, 1966). Goat anti-human IgG conjugate (Hyland Laboratories, Los Angeles, Calif., USA) was used throughout the tests. For detection of EB viral antigens in cultured tumor cells, acetone-fixed smears were prepared as described (Henle et al., 1969) and stained by direct and/or indirect IF techniques for VCA and EA (Henle et al., 1970). As a control we included a marmoset serum which was free of detectable antibodies to EBV antigens but contained antibodies to herpesvirus saimiri (HVS). Other smears were stained solely with anti-human IgG conjugate for the presence of immunoglobulins. 


\section{Histology}

At autopsy, material from tumor, spleen and lymph nodes was removed and fixed for 5 days in buffered formaldehyde solution $(4 \%)$. The specimens were then processed for light microscopy using hematoxylin-eosin staining.

\section{Hematology}

Air-dried smears of peripheral blood drawn at weekly intervals were stained according to the May-Grünwald technique. Differential counts of WBC were recorded and compared with baseline data obtained in our laboratory.

\section{Cytology}

For exclusion of T-cell markers the procedure of Lay et al. (1971) with the modifications of Schwenk et al. (1974) was employed with minor changes. About $2 \times 10^{6}$ cells from rapidly growing cultures were sedimented at $200 \times g$, washed twice in PBS, resuspended in $0.5 \mathrm{ml}$ PBS and incubated with an equal volume of $0.5 \%$ sheep red blood cell (SRBC) suspension for $5 \mathrm{~min}$ in a water bath at $37^{\circ} \mathrm{C}$ with continuous shaking. The cells were then pelleted at $200 \times \mathrm{g}$ and kept at $4^{\circ} \mathrm{C}$ for $1 \mathrm{~h}$. After gentle resuspending they were transferred to a cell counting chamber and examined for rosette formation. For studies of cell morphology, smears were stained by the conventional Leishman-Giemsa technique.

\section{Electron microscopy}

Negative staining of concentrated virus was performed by the common two-step procedure using $2 \%$ phosphotungstic acid (PTA) at pH 7.0 and 7.5 on copper grids coated with Piolofirm (Wacker Chemie GmbH., Munich, Germany) and carbon. Negative stainings were examined for the presence of viral particles with a Siemens 101 electron microscope.

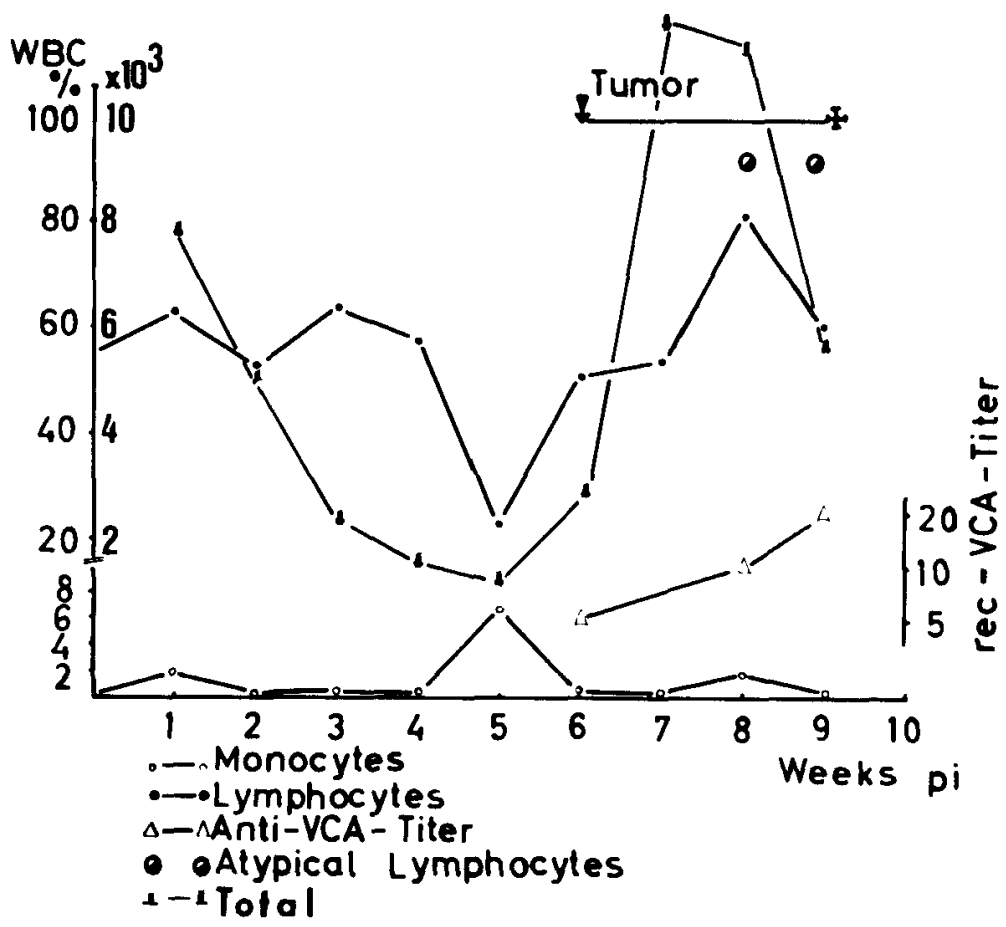

Figure 1

Total WBC, lymphocyte and monocyte counts, as well as development of VCA-antibodies within the tumor-bearing marmoset following injection of active Kaplan virus. 


\section{Lymphocyte cultures}

Lymphocytes were isolated at autopsy from parts of the tumor and spleen. The tissue fragments were minced and teased through a fine teflon-coated steel mesh into medium RPMI 1640 without fetal calf serum (FCS), containing $1 \%$ glutamine, $20 \mathrm{~mm}$ HEPES, $50 \mu \mathrm{g} / \mathrm{ml}$ gentamycin and $2.5 \mu \mathrm{g} / \mathrm{ml}$ amphotericin B. The cell suspensions were then layered on Ficoll-Hypaque gradients (Perper et al., 1968; Thorsby and Bratlie, 1970 ), $\varrho=1.077 \mathrm{~g} / \mathrm{ml}$, and spun at $200 \times g$ for $25 \mathrm{~min}$ at room temperature. Separated lymphocytes were collected, washed three times in medium and resuspended in $3.0-5.0 \mathrm{ml}$ of growth medium RPMI supplemented with $10 \%$ FCS, $1 \%$ glutamine and $100 \mu \mathrm{g} / \mathrm{ml}$ ampicillin. Cultures were set up in duplicate and incubated at $37^{\circ} \mathrm{C}$ in a $5 \% \mathrm{CO}_{2}$-enriched atmosphere. Normal splenic lymphocytes for in vitro transformation assay were prepared and handled as above. Cultures were fed weekly by replacing $50 \%$ of the supernatant with fresh pre-warmed medium. Cell proliferation, as revealed by cluster formation and blastoid transformation, was monitored with a Leitz inverted microscope.

\section{RESULTS}

No signs of clinical disease and no evidence of seroconversion were observed in the animals which received P3HR-1 virus or neutralized Kaplan virus. The same held true for two marmosets inoculated with active Kaplan virus. In one marmoset exposed to non-neutralized Kaplan virus, a marked change in the differential count of WBC was seen 5 weeks PI (Fig. 1). The number of lymphocytes dropped from about $60 \%$ to $23 \%$ and monocytes increased to $7 \%$. One week later these values had returned to normal. At this time, however, enlargement of lymph nodes in the cervical region was discovered and low titers $(1: 5)$ of serum antibodies to EB-VCA could be demonstrated. During the next 2 weeks accelerated tumor growth was recorded, involving the right submandibular
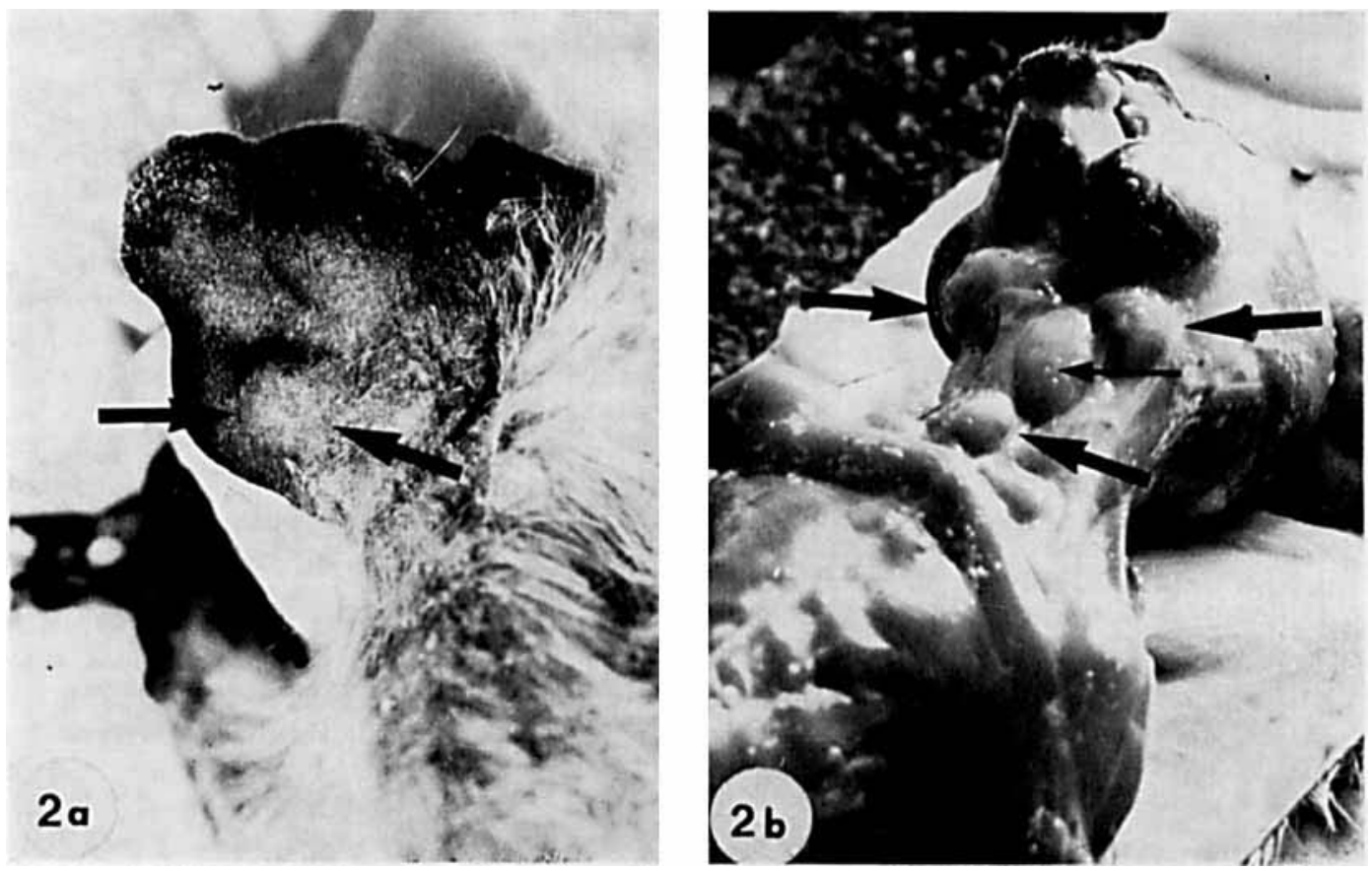

\section{Figure 2}

Close-up of the cervical region of marmoset 794; A : tumor appearance 9 weeks after inoculation; B: view of tumor and enlarged lymph glands (between arrows) at autopsy. Normal salivary gland, small arrow. 
region. Eight weeks PI a solid tumor approximately $0.6 \mathrm{~cm}$ in diameter had developed. Tumor masses were also palpated in the left cervical region encompassing the draining lymph nodes at the site of inoculation. The lymphocyte count rose to $82 \%$ with a few atypical cells present, and serum antibodies to VCA reached a titer of 1:10. At week 9 PI the moribund marmoset was killed. At that time the WBC differential count revealed numerous atypical lymphocytes and the last available serum contained antibodies to VCA at a titer of $1: 20$.

At autopsy the cervical lymph nodes were found to be enlarged up to $0.5 \mathrm{~cm}$ in diameter. A solid tumor measuring $1.0 \mathrm{~cm}$ across with necrosis and hemorrhage, involving the right submandibular gland, was detected (Fig. 2). The spleen was swollen, measuring more than twice its normal size, with tiny superficial nodules and occasional necrosis.

Tumor, lymph nodes, liver and spleen were removed for further studies.

Histologic examination of the tumorous lymph node revealed neoplastic changes of tissue as indicated by numerous foci composed of lymphocytic and reticulum cells embedded in large zones of necrotic material (Fig. 3A). The nucleus of the prominent cell type was large with marginated chromatin. Many nuclei contained multiple nucleoli. Mitotic figures were present (Fig. 3B-C).

The same cell type was also noted in lymph nodes and spleen, although typical foci of tumorous tissue were not recognizable. The liver exhibited lymphocytic infiltrations in the periportal zones but no tumorous alterations were seen in various sections examined.

Data on nucleic acid hybridization performed with DNA from the biopsy material and EBVDNA labelled in vitro are reported elsewhere (Wolf et al., 1975). They showed the presence of virus-specific DNA within the tumor material as well as within DNA derived from the infiltrated spleen.

Cell cultures were initiated from small pieces of tumor and spleen, as well as from peripheral blood. Cell proliferation was observed after 70 days in the tumor-derived culture and after 80 days in the spleen-derived culture. No lymphoblastoid cell lines could be established from peripheral blood.

Both established lines, 794T (tumor) and 794S (spleen), showed the presence of EBV antigencontaining cells ranging from 3 to $5 \%$ of the total cell population. Cells containing EA usually exceeded the number of VCA-positive cells. Production of IgG was found in both lines at an early stage of cultivation in a low percentage $(0.1$ to $0.5 \%)$. None of the lines formed rosettes with SRBC. The cell population consisted of predominantly large blastic cells, with irregularshaped nuclei containing one or more nucleoli. The cytoplasm stained intensely blue (LeishmanGiemsa) and contained a number of small vacuoles. Giant cells with multilobed nuclei were also present (Fig. 4). Cells thus closely resembled cultured BL cells on the basis of their morphological features (Epstein et al., 1966; Pope et al., 1967).

In concentrated supernatants of both lines, as well as in sectioned cells, virus particles of herpes morphology could be detected by electron microscopy (Fig. 5).

For transformation of normal marmoset spleen lymphocytes, supernatants of aged cultures of $794 \mathrm{~S}$ cells were concentrated, as described in "Material and Methods", to yield cell-free preparations of EBV. The lymphocytes were exposed to $0.2 \mathrm{ml}$ of this virus preparation for $2 \mathrm{~h}$ at $37^{\circ} \mathrm{C}$ and subsequently treated as reported above. Four weeks after infection of the cells, a lymphoblastoid line $786 \mathrm{~S}$ became established. These cells produced EBV-related EA and VCA, as revealed by IF techniques in 5 to $10 \%$ of the population. No cell growth was observed with uninfected 786 lymphocytes cultivated in parallel.

\section{DISCUSSION}

Our data indicate that EBV derived from tissue-culture cells of a patient with IM can induce lymphoproliferative disease as expressed

\section{Figure 3}

A : Histologic section of tumor from marmoset 794. Foci of tumor cells surrounded by necrotic tissue. Hematoxylin and eosin, $\times 100$. B-c: Higher magnification of tumorous foci composed of lymphocytic and reticulum cells, $\times 500$. 

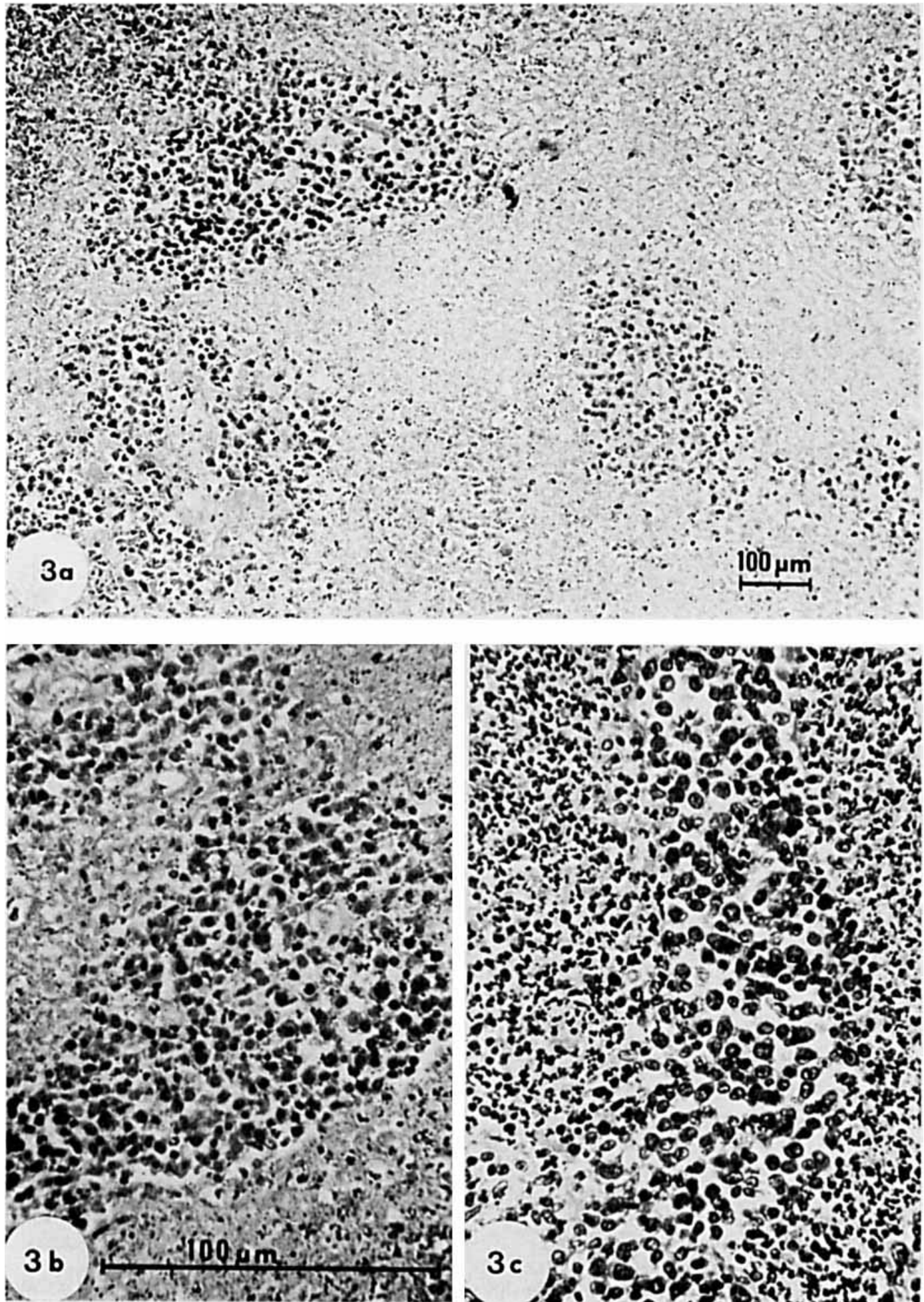

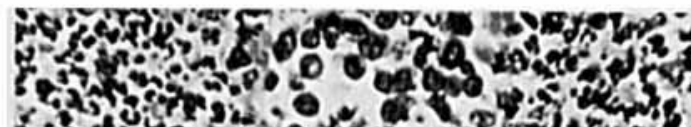

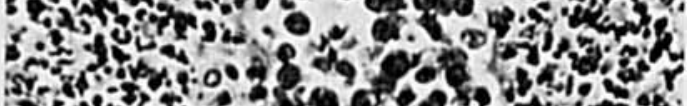



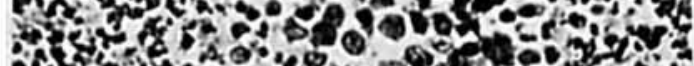

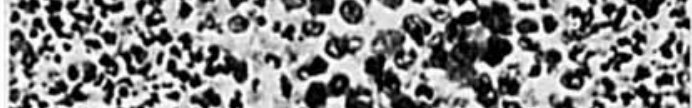

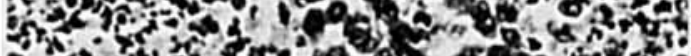

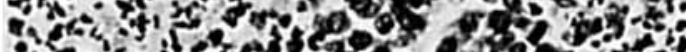

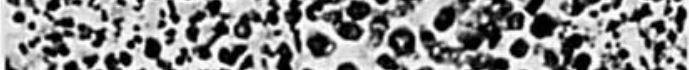

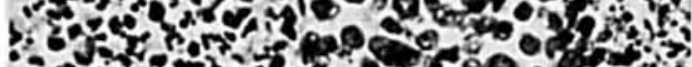

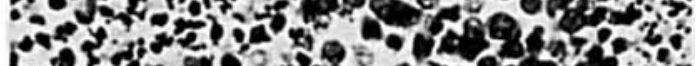
P. Ex S.0Y M-

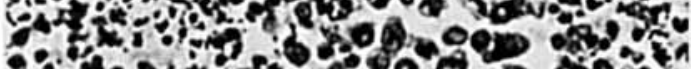

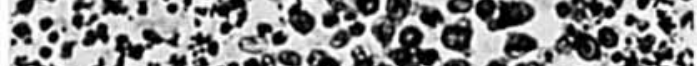
(3) truy

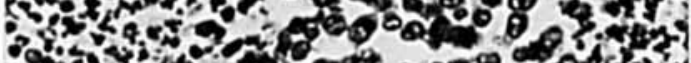

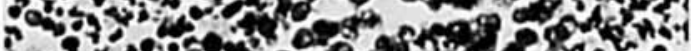

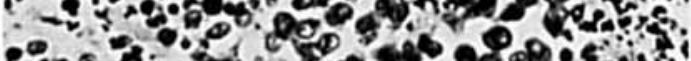

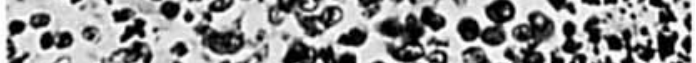

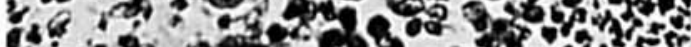



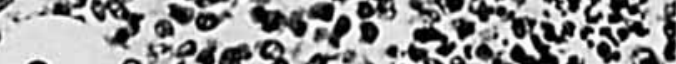
3c 9. 8 \%





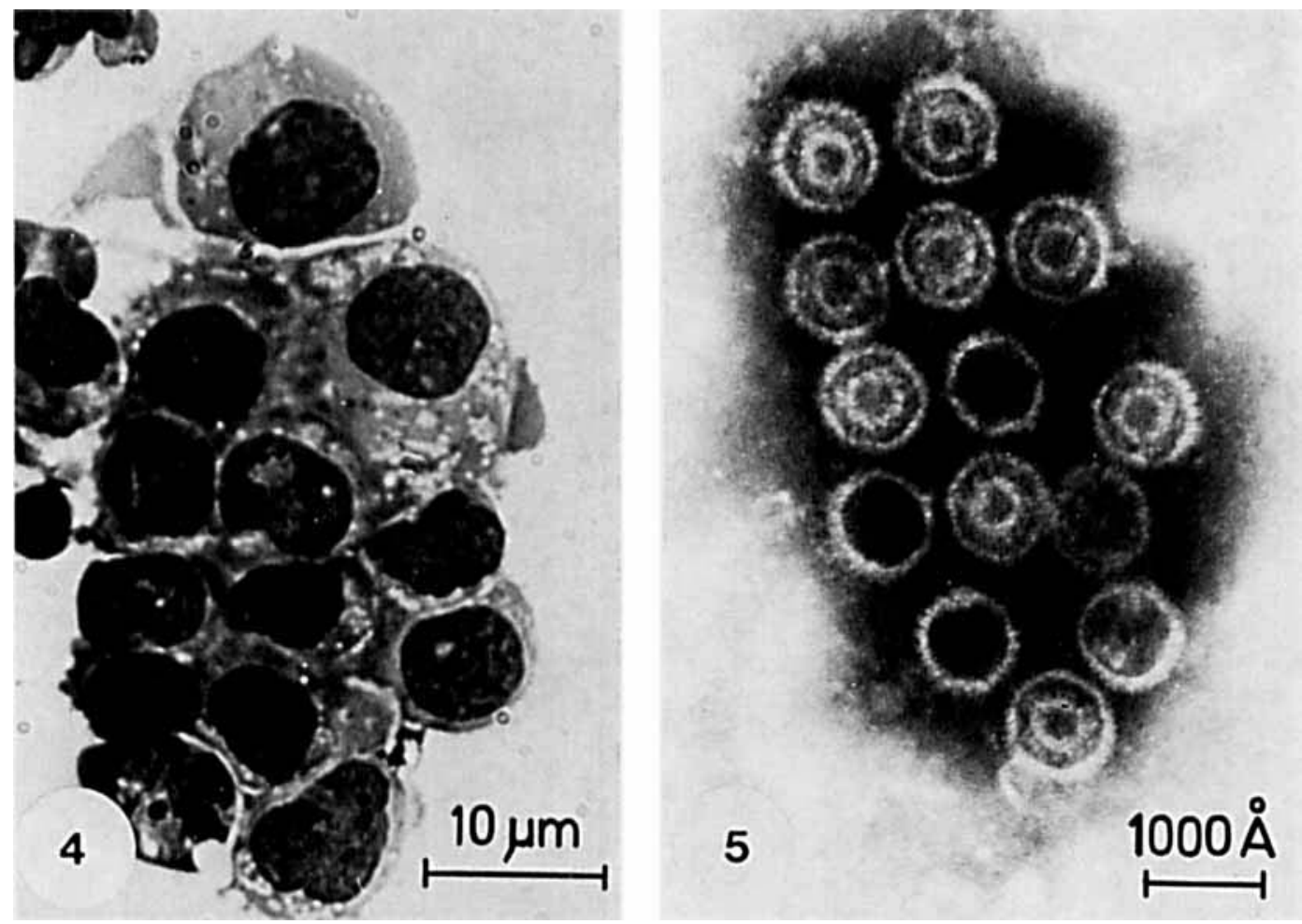

FIGURE 4

Leishman-Giemsa staining of lymphoblastoid tissue culture cells obtained after in vitro cultivation of tumor material $\times \mathbf{i} .800$.

FIGURE: 5

Virus particles, isolated from the supernatant of the 794T lymphoblastoid line, established from the marmoset tumor after negative contrast staining, $\times 120,000$.

by tumor formation in cotton-top marmosets. This is in line with the observations of Shope $e t$ al. (1973), Epstein et al., (1973b) and Falk et al. (1974) who induced tumors in the same species or in an owl monkey, after inoculation of EBV obtained either from an in vitro-transformed marmoset cell line or from EB3 cells of Burkitt tumor origin. Thus, a virus originating from human non-malignant disease may be oncogenic for primates under experimental conditions.

The cellular heterogeneity of the lesion encountered in marmoset No. 794 is consistent with malignant lymphosarcoma. The tumorous material contained EBV-DNA as demonstrated by nucleic acid hybridization (Wolf et al., 1975), and gave rise to lymphoblastoid cell lines synthesizing EBV in 3 to $5 \%$ of the cells. The virus isolated from a line derived from the infiltrated spleen also induced transformation of normal marmoset spleen lymphocytes. The tumor-bearing animal developed low titers of antibodies to EB-VCA in the course of the disease.

The induction of tumor in one of the three marmosets inoculated with active Kaplan virus is rather surprising in view of the low in vitro transforming efficiency of this isolate. The latter appears to be due to the low spontaneous induction rate of the line as revealed by VCAimmunoffuorescence. This might also account for the failure to induce tumors in marmosets with other Kaplan concentrates as reported by Falk and his colleagues (1974).

The animals injected with the P3HR-1 isolate should have received at least 100 times more virus particles, by assuming equal amounts of virus synthesis in VCA-positive P3HR-1 and Kaplan 
cells. The consistent failure to induce tumors with this preparation (Werner et al., 1972b; Falk et al., 1974) corresponds to the lack of transforming activity after infection of umbilical cord lymphocytes (Klein et al., 1972; Miller et al., 1972). The marmoset system appears to offer an approach to test strain differences of various EBV isolates.

Neutralization tests performed in our studies were definitely hampered by the small number of available marmosets and therefore are not very indicative.

In conclusion, we demonstrated tumor induction in one of three cotton-top marmosets after inoculation with EBV derived from a cell line of a patient suffering from IM. Virus isolates from P3HR-1 cells of BL origin failed to induce lymphoproliferative disease in a small number of animals tested.

\section{ACKNOWLEDGEMENTS}

We are indebted to Dr. Hans Gelderblom for his suggestions and help with the electron microscopy studies. The excellent photographic work of Ms. A. Passow and the competent technical assistance of Mrs. U. Baum are gratefully acknowledged. This work has been supported by the Deutsche Forschungsgemeinschaft, Bonn-Bad Godesberg, SFB 118.

\title{
MALADIE LYMPHOPROLIFÉRATIVE CHEZ UN OUISTITI DE L'ESPÈCE SAGUINUS OEDIPUS APRĖS INOCULATION AVEC LE VIRUS D'EPSTEIN-BARR PROVENANT D'UNE MONONUCLÉOSE INFECTIEUSE
}

\begin{abstract}
L'injection d'EBV concentré provenant de cellules de la lignée Kaplan obtenue à partir d'une mononucléose infectieuse a provoqué une lymphoprolifération maligne chez un ouistiti sur trois, six semaines après l'inoculation. Deux autres animaux qui avaient reçu le même isolat après incubation avec du sérum humain contenant des anticorps $n$ 'ont pas développé de tumeurs. L'inoculation de virus concentré provenant de la lignée p $3 H R-1$ de lymphome de Burkitt n'a pas induit de lymphoprolifération chez cinq ouistitis. Trois d'entre eux ont reçu du virus P3HR-1 non neutralisé et les deux autres du virus neutralisé. La tumeur obtenue avec l'isolat Kaplan avait les caractéristiques d'un lymphosarcome. Elle contenait l'ADN spécifique de l'EBV. En outre, des lignées lymphoblastoildes synthétisant l'EBV ont été constituées à partir d'un ganglion cancérisé ainsi que de la rate du singe cancéreux. Le virus recueilli dans ces lignées a transformé des lymphocytes provenant de la rate de ouistitis sains. Chez l'animal cancéreux, les titres d'anticorps anti-VCA ont été faibles pendant toute la durée de la croissance tumorale. Ces observations mettent en évidence le potentiel oncogénique de l'EBV directement obtenu à partir de cellules de mononucléose infectieuse.
\end{abstract}

\section{REFERENCES}

Deinhardt, F., Falk, L. R., and Wolfe, L. G., Transformation of nonhuman primate lymphocytes by Epstein-Barr virus. Cancer Res. 34, 1241-1244 (1974).

Diehl, V., Henle, G., Henle, W., and Kohn, G., Demonstration of a herpes group virus in cultures of peripheral leukocytes from patients with infectious mononucleosis. J. Virol., 2, 663-669 (1968).

de Schryver, A., Friberg, S., JR., Klein, G., Henle, W., Henle, G., De-Thé, G., Clifford, P., and Ho, C. H., Epstein-Barr virus-associated antibody patterns in carcinoma of the postnasal space. Clin. exp. Immunol., 5, 443-459 (1969).
Epstein, M. A., Hunt, R. D., and Rabin, H., Pilot experiments with EB virus in owl monkeys (Aotus trivirgatus): I. Reticuloproliferative disease in an inoculated animal. Int. J. Cancer, 12, 309-318 $(1973 a)$.

Epstein, M. A., Achong, B. G., Barr, Y. M., Zajac, B., Henle, G., and Henle, W., Morphological and virological investigations on cultured Burkitt tumor lymphoblasts (strain Raji). $J$. nat. Cancer Inst., 37, 547-559 (1966).

Epstein, M. A., Rabin, H., Ball, G., Rickinson, A. B., JARvis, J., and Melendez, L. V., Pilot experiments with EB virus in owl monkeys (Aotus 
trivirgatus): II. EB virus in a cell line from an animal with reticuloproliferative disease. Int. J. Cancer, 12, 319-332 (1973b).

Evans, A. S., EB virus, infectious mononucleosis and cancer. The closing of the web. Yale J. biol. Med., 47, 113-122 (1974).

Falk, L., Deinhardt, F., and Wolfe, L., Transformation in vitro of nonhuman primate lymphocytes by Epstein-Barr virus. Clin. Res., 20, 793 (1972).

Falk, L., Wolfe, L., Deinhardt, F., Paciga, J., Dombos, L., Klein, G., Henle, W., and Henle, G., Epstein-Barr virus: transformation of nonhuman primate lymphocytes in vitro. Int. J. Cancer, 13, 363-376 (1974).

Henle, G., and Henle, W., Immunofluorescence in cells derived from Burkitt's lymphoma. J. Bact., 91, 1248-1256 (1966).

Henle, G., Henle, W., Clifford, P., Diehl, V., Kafuko, G. W., Kirya, B. G., Klein, G., Morrow, R. H., Munube, G. M. R., Pike, M. C., Tukei, P. M., and ZIEGLER, J. L., Antibodies to EB virus in Burkitt's lymphoma and control groups. J. nat. Cancer Inst., 43, 1147-1157 (1969).

Henle, G., Henle, W., and Diehl, V., Relation of Burkitt tumor associated herpes-type virus to infectious mononucleosis. Proc. nat. Acad. Sci. (Wash.), 49, 91-101 (1968).

Henle, W., and Henle, G., Evidence for a relation of Epstein-Barr virus to Burkitt's lymphoma and other nasopharyngeal carcinoma. IVth International Symposium on Comparative Leukemia Research. Bibl. Haematol., No. 36, 706-713 (1970).

Henle, W., and Henle, G., Epstein-Barr virus: the cause of infectious mononucleosis. In: P. M. Biggs, G. de-Thé and L. N. Payne (ed.), Oncogenesis and herpes viruses. p. 269-274, International Agency for Research on Cancer, Lyons (1971).

Henle, W., Henle, G., Zajac, B., Pearson, G., WAUBKe, R., and SCRIBA, M., Differential reactivity of human sera with EBV-induced " early antigens". Science, 169, 188-190 (1970).

Hinuma, Y., Koun, M., Yamaguchi, J., Wudarski, D. J., Blakeslef, J. R., and Grace, J. T., JR., Immunofluorescence and herpes-type virus particles in the P3HR-1 Burkitt lymphoma cell line. J. Virol., 1, 1045-1051 (1967).

Klein, G., Dombos, L., and Gothoskar, B., Sensitivity of Epstein-Barr virus (EBV) producer and non-producer human lymphoblastoid cell lines to super-infection with EB virus. Int. J. Cancer, 10, 44-57 (1972).

Lay, W. H., Mendes, N. F., Bianco, $C$., and Nussenzweig, V., Banding of sheep red blood cells to a large population of human lymphocytes. Nature (Lond.), 230, 531 (1971).

Miller, G., Shope, T., Lisco, H., Stitt, D., and Lipman, M., Epstein-Barr virus: Transformation, cytopathic changes and viral antigens in squirel monkey and marmoset leukocytes Proc. nat. Acad. Sci. (Wash.), 69, 383-387 (1972).

Niederman, J. C., McCollum, R. W., Henle, G., and Henle, W., Infectious mononucleosis. Clinical manifestations in relation to $\mathbf{E B}$ virus antibodies. J. Amer. med. Ass., 103, 205-209 (1968).

Perper, R. J., Zee, T. W., and Michelson, M. M., Purification of lymphocytes and platelets by gradient centrifugation. J. Lab. clin. Med., 72, 842-848 (1968).

Pope, J. H., Achong, B. G., Epstein, M. A., and Biddulph, J., Burkitt lymphoma in New Guinea: establishment of a line of lymphoblasts in vitro and description of their fine structure. $J$. nat. Cancer Inst., 39, 933-945 (1967).

Schwenk, H. U., Gimpert, E., Plüss, H. J., Pilgrim, U., and Hitzig, W. H., Lymphocyte markers for B- and T-cells in primary immunodeficiency diseases. Klin. Wschr. 52, 426-432 (1974).

Shope, T., Dechajro, D., and Miller, G., Malignant lymphoma in cotton-top marmosets following inoculation with Epstein-Barr virus. Proc. nat. Acad. Sci. (Wash.), 10, 2487-2491 (1973).

ThorsBy, E., and Bratlie, A., A rapid method for preparation of pure lymphocyte suspension. In: Paul I. Terasaki (ed.), Histocompatibility testing, pp. 655-656, Williams and Wilkins Co., Baltimore (1970).

Werner, J., Henle, G., Pinto, C. A., Haff, R. F., and Henle, W., Establishment of continuous lymphoblast cultures from leukocytes of gibbons (Hylobates lar). Int. J. Cancer, 10, 557-567 (1972a).

Werner, J., Pinto, C. A., Haff, R. F., Henle, W., and HenLe, G., Responses of gibbons to inoculation of Epstein-Barr virus. J. infect. Dis., 126, 678-681 $(1972 b)$.

Wolf, H., Werner, J., and zur Hausen, H., EBVDNA in nonlymphoid cells of nasopharyngeal carcinomas and in a malignant lymphoma obtained after inoculation of EBV into cotton-top marmosets. 39 th Cold Spring Harbor Symp. Quantitative Biol., in press (1975).

Wolf, H., zur Hausen, H., and Becker, V., EBviral genomes in epithelial nasopharyngeal carcinoma cells. Nature New Biol., 244, 245-247 (1973).

Wolfe, L. G., and Deinhardt, F., Epstein-Barr virus: Transformation of nonhuman primate lymphocytes in vitro and subsequent studies in vivo. Lab. Invest., 28, 403 (1973).

zur Hausen, H., Schulte-Holthausen, H,, Klein, G., Henle, G., Henle, W., Clifford, P., and SANTESSAN, L., EBV-DNA in biopsies of Burkitt tumors and anaplastic carcinomas of the nasopharynx. Nature (Lond.), 228, 1056-1058 (1970).

zur Hausen, H., Schulte-Holthausen, H., Wolf, H., Dörries, K., and EgGer, H., Attempts to detect virus-specific DNA in human tumors. II. Nucleic acid hybridizations with complementary RNA of human herpes group viruses. Int. $J$. Cancer, 13, 657-664 (1974). 